\title{
Menata Saat Kini untuk Masa Hadapan: Agenda Transformasi Dari STAIN Ke IAIN*
}

\author{
Ismail Suardi Wekke \\ Sekolah Tinggi Agama Islam Negeri (STAIN) Sorong \\ Email: iswekke@gmail.com
}

\begin{abstract}
ABSTRAK
Perluasan kewenangan sebuah institusi perguruan tinggi perlu disiapkan dengan mengidentifikasi agenda yang diperlukan di masa depan. Betapa sebuah institut yang sebelumnya berbentuk sekolah tinggi, jika tidak disiapkan secara komperehensif pada skala tertentu mengalami kegagapan untuk merespon situasi dan kecenderungan terkini. Untuk itu, artikel ini akan menganalisis keperluan merumuskan agenda dan juga mengidentifikasi pola kelembagaan perguruan tinggi.
\end{abstract}

Kata Kunci: perguruan tinggi, pendidikan Islam, tipologi pendidikan

\section{Pendahuluan}

Perguruan tinggi Islam disebut kewujudan hegemoni Barat \& Kristen (Husaini, 2006). Pandangan ini tidak melihat sepenuhnya keberadaan perguruan tinggi Islam yang tidak saja hanya menggunakan pandangan keilmuan Eropa dan Amerika, namun juga mengadopsi tradisi keilmuan dari wilayah lain seperti Afrika Utara dengan membentuk Fakultas Dirasat Islamiyah di Universitas Islam Negeri Syarif Hidayatullah Jakarta. Aplikasi kaidah ilmiah bukan bersandar pada faham keagamaan tetapi penggunaan metode yang dapat diterima sesuai standar keilmuan yang tidak bertumpu pada aspek normatif. Kepemimpinan Harun Nasution di IAIN Jakarta dengan menenalkan pendidikan non-madzhab melalui pembaruan kurikulum. Juga Mukti Ali di IAIN Yogyakarta pada tahun 1960 memperkenalkan kajian perbandingan agama (Nasution, 1995a). Nasution (1995b) menegaskan perlunya penguatan keislaman pada perguruan tinggi, namun wawasan keislaman itu bukan hanya bertumpu pada doktrin semata melainkan juga menyandingkan dengan metode rasionalitas yang empirik.

Pendidikan tinggi Islam awalnya dijadikan sebagai sarana dakwah. Seiring dengan perjumpaan dengan tradisi akademik secara global. Akhirnya fungsi dakwah melebur dalam tradisi akademik yang diwarnai dari pengalaman perguruan tinggi terkemuka seperti McGill dan Leiden. Pembentukan empat belas IAIN sesungguhnya bentuk reformasi pendidikan Islam yang sebelumnya hanya dalam bentuk madrasah (Nakamura \& Nishino, 1993). Tidak saja dalam peran dakwah tetapi juga pada pemberdayaan masyarakat. IAIN beserta alumninya terjun dalam peran-peran kemasyarakatan. Tidak saja itu, alumni perguruan tinggi Islam kemudian bisa

\footnotetext{
* Artikel disiapkan dalam rangka menyongsong Alih Status STAIN Sorong ke IAIN Sorong. Sebagai bahan diskusi dalam rangka Rapat Koordinasi Alih Status STAIN Sorong ke IAIN Sorong, Jakarta, 15 Mei 2019.
} 
bersanding dengan lulusan perguruan tinggi lain dalam aktivitas kebangsaan termasuk menjadi anggota parlemen, penyelenggara pemilihan umum, dan posisi politik lainnya. Termasuk jabatan walikota, bupati, gubernur, dan menteri yang merupakan bagian dari cita-cita politisi. Saat ini di Kementerian Agama terdapat tiga orang dosen universitas Islam negeri yang sementara memegang jabatan di posisi puncak masing-masing sebagai direktur jenderal dan sekretaris jenderal.

Kajian khusus terkait dengan perguruan tinggi Islam belum menjadi perhatian utama. Bahkan Al Attas sekalipun hanya mengemukakan gagasan tentang pendidikan Islam (Al-Attas, 1980). Adapun potret terkait dengan perguruan tinggi hanya dikaji dalam pandangan dunia Arab dan bukan Islam (Eickelman, 1992). Sementara kajian pendidikan tinggi Islam di Indonesia terkait dengan kohesi sosial (Kraince, 2007), toleransi beragama (Saeed, 1999), keberlanjutan \& konflik (Lukens-Bull, 2013), dan kurikulum (Hashim \& Langgulung, 2008). Kesemuanya menunjukkan bahwa diperlukan identifikasi terkait dengan kelembagaan perguruan tinggi dan agenda yang melingkupinya. Artikel ini akan menganalisis agenda perguruan tinggi dan juga mengidentifikasi model perguruan tinggi. Dengan dua pembahasan ini, dapat dijadikan sebagai kajian dalam rangka transformasi kelembagaan perguruan tinggi.

\section{Menengok Sejenak ke Masa Lalu}

Tahun 1997 fakultas filial ditransformasi menjadi tiga puluh tiga STAIN. Tanpa melalui pengusulan dari fakultas-fakultas yang ada di seluruh penjuru Indonesia. Semuanya merupakan kebijakan di tingkat kementerian. Selanjutnya, pendirian perguruan tinggi baru di Majene atau penegerian perguruan tinggi di Kota Sorong, Jayapura, dan Bengkalis, dibentuk langsung dengan status sekolah tinggi. Semua fakultas filial yang beralihstatus menjadi STAIN sudah bertransformasi ke IAIN. Bahkan diantaranya sudah berbentuk universitas, seperti Mataram, dan Banten. Termasuk STAIN Al-Fatah Jayapura yang sudah bertransformasi ke IAIN Fattahul Muluk Papua pada tahun 2018 bersama dengan IAIN Bone, IAIN Parepare, IAIN Kediri, dan IAIN Bangka Belitung. STAIN yang ada saat ini, semuanya hanya pendirian setelah 1997. Lima STAIN yang bertranformasi menjadi IAIN Pada tahun 2018 merupakan bagian dari STAIN yang dibentuk pada tahun 1997.

Perguruan tinggi Islam menjadi instrumen dalam modernisasi Islam di Indonesia (Jabali \& Jamhari, 2002). Seriring dengan meningkatnya minat dan harapan masyarakat dalam pendidikan tinggi, maka IAIN kemudian ditransformasi menjadi universitas. Hanya saja, dalam proses itu, paradigma keilmuan di masing-masing institusi dipraktikkan secara berbeda, setidaknya setelah lima belas tahun terlewati. Untuk UIN Jakarta bahkan sudah tujuh belas 
tahun. Untuk kasus UIN Alauddin, diskusi pola pengembangan ilmiah hanya dikemukakan dalam satu artikel (Arsyad, 2007). Namun tidak dalam bentuk blue print perguruan tinggi. Sehingga hanya dibaca secara parsial. Demikian pula gagasan Mathar tentang pemikiran Islam yang terbit setelah proses transformasi kelembagaan UIN selesai. Dokumen ini bukan kelengkapan dalam proses alih status perguruan tinggi tetapi pidato pengukuhan guru besar (Mathar, 2007). Dua dokumen ini tidak menjadi dasar pijakan dalam pengembangan perguruan tinggi, sehingga tidak ada desain keilmuan yang dijadikan sebagai panduan dalam pengelolaan akademik. Termasuk tidak tersedianya berkala ilmiah atau jurnal yang bereputasi yang dijadikan sebagai komunikasi akademik secara global.

Sementara UIN Maliki Malang sejak awal selalu mengemukakan bagian diskusi pengembangan perguruan tinggi untuk dijadikan pijakan khalayak perguruan tinggi (Suprayogo, 2009; Suprayogo, 2004; Suprayogo, 1999). Tidak saja terkait dengan visi, tetapi rumusan pengembangan kurikulum secara operasional (Muhaimin, 2005). Secara berkala, STAIN Malang memublikasikan dinamika perguruan tinggi yang terbit tahunan merupakan kumpulan catatan historis maupun gagasan civitas akademika yang berhubungkai dengan pengembangan perguruan tinggi. Catatan tahunan diterbitkan, termasuk pula pengalaman penjaminan mutu yang dihimpun dalam buku tersendiri. Ini diterbitkan terkait dengan International Conference on Qualitiy Assurance in Higher Education.

Pertanggung jawaban rektor secara khusus menyorot terkait transformasi ke universitas (Abdullah, 2006). Ide penyatuan keilmuan dimulai dengan istilah integrasi (Minhaji, \& Ahmad, 2003). Selanjutnya disebut pula dengan pendekatan integratif-interkonektif (Abdullah, 2006). UIN Sunan Kalijaga Yogyakarta secara khusus diidentifikasi sebagai bentuk pengembangan institusi yang menjadikan paradigm keilmuan sebagai pijakan awal untuk berdiskusi (Kersten, 2018). Tidak hanya itu, pengembangan sarana kampus juga berpandukan pada prinsip universal dan global. Masjid dibentuk sebagai laboratorium keagamaan. Jika digunakan hanya dalam lima jam sehari, berarti ada sembilan belas jam yang sia-sia. Dalam porsi ini, masjid kampus di Yogyakarta juga digunakan sebagai tempat belajar dan juga aktivitas lain seperti kantin. Dilengkapi pula dengan akses yang memudahkan bagi penyandang disabilitas untuk menjangkau semua sarana yang tersedia.

Pengalaman UIN Suska Pekanbaru menjadikan pijakan budaya Melayu sebagai poros pengembangan. Ini diiplementasikan dalam bentuk bangunan dan ornamen kampus. Termasuk prosesi seremonial yang mengadopsi kekhasan tenun dan budaya Melayu. Hanya saja, diskursus keilmuan yang dijadikan sebagai panduan tidak digaungkan sebagai bagian dari citra utama 
perguruan tinggi. Walaupun dalam proses tranformasi digunakan istilah tertentu untuk digunakan sebagai istilah untuk memandu keilmuan.

Mengawali transformasi enam universitas Islam, UIN Syarif Hidayatullah pada tahun 2002 diresmikan. IAIN yang selanjutnya menjadi UIN dituntut untuk memenuhi harapan sosial dan sekaligus harapan akademik. Sehingga mulai dibuka jurusan kedokteran, dan bahkan ilmu sosial berdiri sendiri sebagai sebuah fakultas. Tanpa meninggalkan khazanah keislaman yang menganut tradisi Mesir dengan pembukaan fakultas dirasah Islamiyah yang memenuhi kriteria Universitas Al Azhar. Lulusan fakultas ini dapat diterima pada jenjang magsiter setelah menempuh ujian kualifikasi. IAIN menjadi bagian dari pengembangan intelektual muslim dengan adanya pembaruan yang dilaksanakan sesuai dengan kecenderungan lingkungan (Azra, 2012).

Walaupun demikian, perbincangan terkait universitas Islam masih mendapat perhatian walaupun hanya letupan ide di forum akademik (Muqoyyidin, 2012). Potret historis dikemukakan Suheri (2014). Juga rekaman perkembangan terkait alih status (Ritaudin, 2017). Artikel yang mengkaji secara khusus institusi perguruan tinggi keagamaan Islam tersebar di penjuru Indonesia antara lain Malang (Muslimin, 2012), Makassar (Rais, 2017), Surabaya (Nasiruddin, 2017), Padang (Fahmi \& Aswirna, 2016), Cirebon (Kurniawan \& Sumadi, 2016), Surakarta (Bakri, Purwanto \& Efendi, 2017), Tulung Agung (Sulistyorini, 2015), Kendari (Syahrul, 2016), dan Palu (Hidayat, 2014). Kesembilan lokasi yang menjadi pembahasan dapat dijadikan sebagai studi kasus bahwa transformasi perguruan tinggi masing-masing berkembang sesuai dengan kondisi lokal tetapi tidak mendapatkan supervisi dari pemangku kepentingan sehingga tidak menuju pada arah yang sama untuk memenuhi agenda keumatan.

\section{Agenda Saat Kini}

Sebelum melangkah lebih jauh, proses alih status seperti STAIN Sorong menjadi IAIN Sorong perlu memperhatikan agenda atmosfer akademik. Tidak hanya semata yang berhubungkait dengan dokumen dan fasilitas kampus sebagai bagian yang juga sama pentingnya dengan semua unsur yang lain. Bukan pula soal uang semata dan sumber daya, melainkan semangat mengatasi keterbatasan (Wekke, 2013). Dapat dimulai dengan mengidentifikasi keperluan yang akan wujud di masa yang akan datang. Sementara itu, Sorong \& Papua Barat merupakan lingkungan strategis yang perlu menjadi acuan utama dan pertama (Wekke, 2015).

Pertama, paradigma keilmuan. Pendirian perguruan tinggi keagamaan Islam mengusung semangat keislaman. Maka, proses akademik tidak boleh hanya mengadopsi keperlu ilmu pengetahuan tetapi juga terkait dengan bimbingan wahyu terhadap akal dan selanjutnya pada 
ilmu pengetahuan. Alih status IAIN Kendari, IAIN Manado, dan IAIN Ambon diantaranya, tidak menunjukkan percakapan tentang pola keilmuan yang akan dikembangkan. Begitu pula dengan UIN Raden Intan, UIN Raden Fatah, dan UIN Mataram. Walaupun dalam proses transformasi selalu menyertakan ide-ide keilmuan dengan membuat sebuah pola sebagaimana yang digunakan UIN Maulana Malik Ibrahim, Malang dengan istilah pohon ilmu, namun pada praktik tata kelola usai peresmian tidak lagi digunakan sebagai dasar kebijakan. Terdapat istilah multicultural sebagai sebuah subyek yang menjadi tema utama. Sementara Kendari menggunakan istilah transdisiplin untuk menunjukkan metode yang digunakan dalam aktivitas perguruan tinggi.

Termasuk dalam kaitan ini memungkinkan untuk membentuk major dan minor. Kolej Universiti Islam Selangor memberikan porsi kurikulum secara khusus pada setiap jurusan. Sebagai contoh jurusan Quran dan Sunnah diberi peluang untuk magang di perusahaan Samsung. Pola ini dikembangkan supaya lulusan jurusan Quran dan Sunnah juga menguasai kemampuan teknologi digital yang tidak bisa ditinggalkan pada abad ini. Sehingga lulusan KUIS bisa mengembangkan aplikasi dengan sistem android dengan pengayaan konten yang berbasis keilmuan. Sehingga lulusan jurusan Ilmu Alquran dan Tafsir di perguruan tinggi keagamaan Islam juga menguasai kemampuan teknologi informasi dan disiapkan untuk turut mengambil peran dalam era revolusi industri 4.0.

Dengan adanya paradigma keilmuan akan memberikan landasan bagi pengembangan program studi atau jurusan. Dengan status perguruan tinggi Islam, maka kecenderungan untuk mengelola jurusan dengan basis keilmuan Islam tentu merupakan mandat undang-undang. Hanya saja, sebagai contoh jurusan Manajemen Informasi Syariah. Penamaan program studi seperti ini, tidak melalui kajian dengan menggunakan paradigm keilmuan. Sebab informasi tidak mengenal diversifikasi antara konvensional dan syariah. Berbeda dengan sistem perbankan atau ekonomi yang mengenal distingsi antara syariah dan konvensional.

Kedua, nuansa akademik. Aktivitas yang dilaksanakan bisa saja terkait dengan aktivitas keagamaan tetapi dibarengi knowledge management. Walaupun melaksanakan peringatan Isra Mi'raj tetapi naskah ceramah diterbitkan dalam bentuk buku kecil walau dengan bentuk buku elektronik. Selanjutnya ditempatkan di laman web kampus sehingga siapapun bisa mengunduh naskah tersebut. UIN Malang sebagai contoh memadukan antara tradisi keagamaan dengan tradisi akademik (Minhaji, 2013). Dengan demikian atmosfer akademik akan ditopang dengan aktivitas keagamaan yang juga menjadikan instrumen keilmuan sebagai bagian integral dalam pelaksanaan keduanya (Mulyono \& Wekke, 2018).

Kultur akademik yang dibangun idealnya sudah mengalami konvergensi dengan kehadiran teknologi informasi. Pembelajaran yang dilaksanakan tidak lagi bertumpu pada 
teknologi informasi sebagai media pembelajaran tetapi justru dijadikan sebagai alat interaksi. Dengan kondisi seperti ini, maka pola pembelajaran menggunakan metode blended learning sudah diperlukan. Disamping pertimbangan efektifitas, juga akan memangkas biaya yang dikeluarkan untuk mendatangkan pakar dalam rangka kuliah umum atau kuliah tamu.

Pusat kecemerlangan (center of excellence) di tingkat perguruan tinggi perlu dibentuk untuk menjadi bagian dalam pengembangan riset dan publikasi. Setiap perguruan tinggi tidak harus mengembangkan cabang keilmuan secara keseluruhan. Bisa jadi, satu perguruan tinggi hanya fokus pada kajian keilmuan tertentu seperti hadis saja, atau tafsir saja. Maka, sumber daya yang diterima dalam formasi kepegawaian semata-mata hanya untuk memenuhi pengembangan keilmuan tersebut. Tidak lagi seperti sekarang, semua perguruan tinggi mengelola jurusan pendidikan agama Islam. Akibatnya, guru agama mengalami over-supply, sementara terdapat pula keluhan dimana lembaga pendidikan justru tidak dapat merekrut guru agama karena ketiadaan sumber daya.

Ketiga, sinergi keilmuan dengan pusat-pusat kecemerlangan akademik dunia. Walaupun demikian, tidak membatasi diri dengan satu wilayah saja. Salah satu keunggulan pendidikan Islam karena bisa bergerak dan membangun kolaborasi dengan siapapun di seluruh penjuru dunia (Welch, 2012). Periode 1990-2000 dimana dosen atau calon dosen dikirim belajar ke McGill Kanada. Dengan kehadiran dosen yang berinteraksi dengan pendidikan Kanada XXX.

Kerjasama dengan perguruan tinggi atau lembaga global sebuah kesempatan untuk menggerakkan pusat-pusat kecemerlangan. Identifikasi niche atau topik-topik fokus riset sebagai keunggulan komparatif dengan melalui kerjasama akan menjadi isu utama. Perguruan tinggi tidak lagi hanya focus pada satu monodisiplin. Dimungkinkan untuk mengkaji topik lingkungan dari pelbagai sudut pandang keilmuan. IAIN memiliki kesempatan untuk turut berperan secara global melalui core keilmuan agama Islam yang terkai secara langsung dengan kehidupan manusia.

Keempat, fasilitas yang terkait dengan keperluan akademik. Dibutuhkan ruang-ruang permanen yang juga mengadaptasi perkembangan teknologi paling mutakhir kalau tidak dikatakan yang paling canggih. Termasuk bangunan yang memberi akses kepada penyandang disabilitas. Demikian pula cerminan nuansa lokal dengan material yang paling modern. Dengan sebuah catatan yang sangat penting, tidak memungkinkan bangunan Eropa ditempatkan di wilayah tropis. Ventilasi dan juga pencahayaan tidak bisa dinafikan. Begitu pula dengan penggunaan pendingin ruangan yang berlebihan patut dihindari. Ketika memasuki bangunan di STAIN Sorong, maka mata pengunjung akan langsung disuguhi dengan ornament Papua. Sehingga keberadaan perguruan tinggi akan menjadi pusat pelestarian khazanah lokal. Bukan 
sebaliknya, perguruan tinggi yang justru membunuh wawasan dan kearifan lokal yang sudah berkembang di masyarakat.

\section{Akhirat Class University: Pemetaan Tipologi Kampus}

World Class University menjadi kecenderungan pendidikan tinggi saat ini (Deem, Mok, \& Lucas, 2008). Tetapi itu bukan satu-satunya bentuk perguruan tinggi. Bisa saja perguruan tinggi memilih model antara lain entrepreneur university (Amiri, Kavousy \& Husseini, 2009; Bird \& Allen, 1989), teaching and learning university (Laurillard, 2002; Martin, 1999), community engagement university (Winter, Wiseman \& Muirhead, 2006; McNall, Reed, Brown \& Allen, 2009), adaptive university (Sporn, 1999), dan comprehensive university (Winter, Taylor \& Sarros, 2000). Kelima model perguruan tinggi tersebut, bisa jadi tidak sesuai dengan kondisi yang sama dengan perguruan tinggi lain. Sehingga memungkinkan untuk dirumuskan model perguruan tinggi yang disesuaikan dengan kondisi perguruan tinggi tersendiri.

Jika World Class University dijadikan sebagai salah satu model ideal sebuah kampus, maka bisa jadi perlu dirumuskan Akhirat Class University. Perguruan tinggi dengan orientasi pada akhirat. Maka perguruan tinggi dengan standar akhirat menggunakan pola penguatan pada guru mengaji, melatih para khatib untuk memutakhirkan tema-tema khutbah dengan tetap berpijak pada landasan Quran dan Sunnah, dan merespon masalah-masalah keumatan dengan cepat. Termasuk pula menyiapkan lulusan yang akan berkiprah sebagai dai di daerah-daerah terpencil dan wilayah dakwah khusus lainnya. Jika hanya menggunakan World Class University, bisa jadi masyarakat akan terabaikan dan justru lebih fokus pada pengurusan riset berbanding keperluan utama masyarakat. Termasuk kampus menjadi institusi yang mengusahakan perluasan kesempatan belajar (Wekke, 2018). Dengan demikian bisa saja ada program-program yang unik dan hanya satu-satunya yang dikelola kampus yang tidak tersedia di kampus lain.

Jika istilah ini tidak berterima, maka bisa saja digunakan Community Based University (Henggeler, Schoenwald, \& Pickrel, 1995). Perguruan tinggi menjadikan masyarakat sebagai orientasi. Namun, kalau tuntutan untuk melakukan publikasi. Ini bukan aktivitas yang sukar, sebab dengan orientasi masyarakat itu akan diterbitkan naskah khutbah, policy brief, atau temuan terkait dengan keperluan masyarakat sekitar. Pada konteks ini, bisa pula dikembangkan sinergi antar perguruan tinggi, masyarakat, dan industry. Dengan triple helix akan memberikan kesempatan secara luas dalam pengembangan aktivitas perguruan tinggi (Leydesdorff \& Etzkowitz, 1998). Perguruan tinggi di Jepang menjadi bagian dalam transfer teknologi dari industri ke masyarakat (Collins \& Wakoh, 2000). Ini menjadi tanda betapa perguruan tinggi 
memiliki kekuatan untuk melakukan dinamisasi masyarakat. Mengabaikan potensi ini, akan menjadikan kepercayaan masyarakat semakin surut dari waktu ke waktu.

Sementara itu keterlibatan masyarakat di perguruan tinggi Malaysia dapat dilihat dari keberadaan masjid. Sebagai pusat ibadah, masjid ditempatkan di bagian terdepan (dalam arti geografis) kampus. Bahkan ketua Pusat Islam di perguruan tinggi diberi kewenangan setara dengan dekan. Masjid juga sebagai bagian pembelajaran, mata kuliah kokurikulum dilaksanakan secara terpadu di Masjid dengan pilihan mata kuliah antara lain manajemen masjid. Demikian pula kuliah-kuliah umum secara terjadwal baik mengikuti waktu shalat maupun juga seminar dengan tema-tema pilihan. Masjid juga dijadikan masyarakat umum untuk menyelesaikan kewajiban yang menjadi syarat ketetapan Jabatan Kemajuan Islam masing-masing negeri. Seperti syarat untuk kursus pra-nikah bagi calon pasangan mempelai, itu ditempuh di masjid kampus. Termasuk masjid kampus seperti Universiti Sultan Zainal Abidin, Kuala Terengganu secara rutin melaksanakan ibadah umrah dan haji dengan silabus yang disusun oleh masjid kampus. Keberadaan masjid dijadikan sebagai kantor untuk unit pengumpul zakat, dan aktivitas yang terkait dengan keumatan. Pusat Islam dijadikan sebagai bagian integral kampus untuk dijadikan pendukung perguruan tinggi. Ini sebuah kesempatan mewadahi keberagamaan mahasiswa dan warga kampus secara keseluruhan (Wekke, Hermawanto \& Ashrori, 2016). Mengelola keberagamaan dengan menjadikan sebagai kegiatan kampus akan memberikan dampak tidak saja untuk keperluan akademik tetapi terkait dengan religiusitas (Sahlan \& Wekke, 2014).

Kalaulah masjid hanya menjadi tempat sholat semata-mata, bisa jadi itu fenomena masjid di luar kampus. Tetapi masjid kampus harus menjadi bagian dari pengelolaan tri dharma perguruan tinggi itu sendiri. Bangunan dan aktifitas masjid bagian dalam pembentukan profil lulusan. Sebagaimana masjid Salman di Bandung. Secara khusus dijadikan sebagai tempat untuk memberikan penguatan pemahaman dan praktik keagamaan bagi mahasiswa Institut Teknologi Bandung. Ketika alumni ITB semasa beraktivitas di kampus juga aktif di masjid Salman, maka akan saling melengkapi keperluan mahasiswa. Gedung perkuliahan untuk mengasah kemampuan kognitif sementara masjid menjadi tempat untuk menempah aspek spiritual.

\section{Penutup}

Artikel ini menganalisis agenda perguruan tinggi terkait dengan kesiapan untuk melakukan transformasi kelembagaan. Menelusuri perguruan tinggi keagamaan yang sudah menyelesaikan proses transformasi lima belas tahun lalu menjadi sebuah cerminan untuk menyiapkan perguruan tinggi dalam kaitan dengan proses yang sama. Untuk itu perlu 
memperhatikan rangkaian proses transformasi tiga perguruan keagamaan Islam yaitu UIN Sunan Kalijaga, UIN Syarif Hidayatullah Jakarta, dan UIN Maulana Malik Ibrahim Malang. Ketiga perguruan tinggi dalam proses transformasi menyiapkan diri menjadi pusat kecemerlangan sehingga dalam perjalanan waktu dapat memainkan peran sesuai dengan keperluan terkini dan masa sekarang, bukannya memenuhi keperluan masa lalu.

\section{Daftar Pustaka}

Abdullah, M. A. (2006). Islamic studies di perguruan tinggi: pendekatan integratif-interkonektif. Pustaka Pelajar.

Abdullah, M. A. (2006). Transformasi IAIN Sunan Kalijaga menjadi UIN Sunan Kalijaga. Laporan pertanggungjawaban Rektor UIN Sunan Kalijaga periode, 2006-2010.

Al-Attas, M. N. (1980). The concept of education in Islam. Muslim Youth Movement of Malaysia.

Amiri, S. R. S., Kavousy, E., \& Husseini, A. S. (2009). Strategies for creating entrepreneur university. European Journal of Social Sciences, 11(3), 496-506.

Arsyad, A. (2007). Universitas islam: integrasi dan interkoneksitas sains dan ilmu agama menuju peradaban islam universal. Jurnal Tsaqafah, Jurnal Peradaban Islam, 3.

Azra, A. (2012). Pendidikan Islam tradisi dan modernisasi di tengah tantangan millennium III. Jakarta: Kencana Prenada.

Bakri, S., Purwanto, P., \& Efendi, M. (2017). Pemetaan Kebutuhan Sarana Prasarana Menjadi UIN Surakarta. IAIN Surakarta.

Bird, B. J., \& Allen, D. N. (1989). Faculty Entrepreneur/Ship in Research University Environments. The Journal of Higher Education, 60(5), 583-596.

Collins, S., \& Wakoh, H. (2000). Universities and technology transfer in Japan: Recent reforms in historical perspective. The Journal of Technology Transfer, 25(2), 213-222.

Deem, R., Mok, K. H., \& Lucas, L. (2008). Transforming higher education in whose image? Exploring the concept of the 'world-class' university in Europe and Asia. Higher education policy, 21(1), 83-97.

Eickelman, D. F. (1992). Mass higher education and the religious imagination in contemporary Arab societies. American ethnologist, 19(4), 643-655.

Etzkowitz, H., \& Leydesdorff, L. (1995). The Triple Helix--University-industry-government relations: A laboratory for knowledge based economic development. EASST review, 14(1), 14-19.

Fahmi, R., \& Aswirna, P. (2016). Studi deskriptif tentang alih status Institut Agama Islam Negeri (IAIN) menjadi Universitas Islam Negeri (UIN) Imam Bonjol Padang. TADRIS: Jurnal Pendidikan Islam, 11(1), 89-115.

Hashim, C. N., \& Langgulung, H. (2008). Islamic religious curriculum in Muslim countries: The experiences of Indonesia and Malaysia. Bulletin of Education \& Research, 30(1), 1-19.

Henggeler, S. W., Schoenwald, S. K., \& Pickrel, S. G. (1995). Multisystemic therapy: Bridging the gap between university-and community-based treatment. Journal of consulting and clinical psychology, 63(5), 709.

Hidayat, M. U. (2014). Persepsi warga kampus STAIN Datokaramapalu tentang penciptaan suasana religius kampus untuk menunjang pencapaian kualitas akademik (Menyongsong alih status kelembagaan STAIN Menjadi IAIN). Istiqra: Jurnal Hasil Penelitian, 2(1), 124.

Husaini, A. (2006). Hegemoni Kristen-Barat dalam studi Islam di perguruan tinggi. Gema insani.

Jabali, F., \& Jamhari, (2002). IAIN \& Modernisasi Islam di Indonesia. Jakarta:Logos. 
Kersten, C. (2018). Berebut Wacana: Pergulatan Wacana Umat Islam Indonesia Era Reformasi.

Kraince, R. G. (2007). Islamic higher education and social cohesion in Indonesia. Prospects, 37(3), 345-356.

Kurniawan, A., \& Sumadi, S. (2016). Manajemen strategik dengan pendekatan balanced scorecard di IAIN Syekh Nurjati dalam upaya transformasi menjadi UIN. Holistik, 1(1).

Laurillard, D. (2002). Rethinking university teaching: A conversational framework for the effective use of learning technologies. Routledge.

Lewis, H. R. (2006). Excellence without a soul: How a great university forgot education (pp. 1995-2003). New York: PublicAffairs.

Leydesdorff, L., \& Etzkowitz, H. (1998). The triple helix as a model for innovation studies. Science and public policy, 25(3), 195-203.

Lukens-Bull, R. (2013). Islamic higher education in Indonesia: Continuity and conflict. Springer.

Martin, E. (1999). Changing academic work: developing the learning university. McGraw-Hill Education (UK).

Mathar, M. (2007). Kimiawi Pemikiran Islam: Arus Utama Islam di Masa Depan.

McNall, M., Reed, C. S., Brown, R., \& Allen, A. (2009). Brokering community-university engagement. Innovative Higher Education, 33(5), 317-331.

Minhaji, A. (2013). Tradisi akademik di perguruan tinggi. Suka-Press.

Minhaji, A., \& Ahmad, K. B. (2003). Transformasi IAIN Menuju UIN: Sebuah Pengantar," dalam Jarot Wahyudi dkk. Menyatukan Kembali Ilmu-ilmu Agama dan Umum (Upaya mempersatukan Epistemologi Islam dan Umum). Yogyakarta: Suka Press.

Muhaimin. (2005). Pengembangan kurikulum pendidikan agama Islam: di sekolah, madrasah, dan perguruan tinggi. RajaGrafindo Persada.

Mulyono, M., \& Wekke, I. S. (2018). Academic and Culture Development Strategy Management for Islamic Higher Education In Indonesian. IOP Conference Series: Earth and Environmental Science (Vol. 175, No. 1, p. 012163). IOP Publishing.

Muqoyyidin, A. W. (2012). Universitas Islam center of excellences: Integrasi dan interkoneksitas ilmu-ilmu agama dan sains menuju peradaban Islam kosmopolitan.

Muslimin, I. (2012). Studi Kepemimpinan Prof. Imam Suprayogo dalam Mengimplementasikan Perubahan Kelembagaan UIN Maulana Malik Ibrahim Malang. El-QUDWAH.

Nakamura, M., \& Nishino, S. (1993). Islamic higher education in Indonesia. Higher Education Policy, 6(2), 51-54.

Nasiruddin, N. (2015). Kebijakan pengembangan program studi di UIN Sunan Ampel Surabaya setelah alih status dari IAIN menjadi UIN Sunan Ampel Surabaya. Doctoral dissertation. UIN Sunan Ampel Surabaya).

Nasution, H. (1995). Islam rasional: Gagasan dan pemikiran. Mizan.

Nasution, H. (1995). Keilmuan Agama Islam Pada Perguruan Tinggi Agama Islam. Dalam Anonimus, Sarasehan Pengembangan Perguruan Tinggi Agama Islam pada IAIN Sunan Gunung Djati dan PTAIS Jawa Barat. Bandung: IAIN Sunan Gunung Djati, 55-60.

Rais, M. (2017). Kapasitas UIN Alauddin Makassar pasca alih status. EDUKASI: Jurnal Penelitian Pendidikan Agama dan Keagamaan, 15(3).

Ritaudin, M. S. (2017). Promosi Islam Moderat Menurut Ketum (MUI) Lampung Dan Rektor Universitas Islam Negeri (UIN) Raden Intan Lampung. Jurnal TAPIs, 13(2), 48-73.

Saeed, A. (1999). Towards religious tolerance through reform in Islamic education: The case of the state institute of Islamic studies of Indonesia. Indonesia and the Malay World, 27(79), 177-191.

Sporn, B. (1999). Adaptive University Structures: An Analysis of Adaptation to Socioeconomic Environments of US and European Universities. Higher Education Policy Series 54. Taylor and Francis, Inc., 325 Chestnut Street, Philadelphia PA 19106. 
Suheri, S. (2014). Refleksi historis konversi STI ke UIN. Tarbiyatuna: Jurnal Pendidikan Islam, 7(1), 1-19.

Sulistyorini, S. (2015). Perubahan Status Organisasi Perguruan Tinggi Islam (Studi Kasus IAIN Tulungagung). Dinamika Penelitian, 15(2), 133-150.

Suprayogo, I. (1999). Reformulasi Visi Pendidikan Islam. STAIN Press.

Suprayogo, I. (2004). Pendidikan berparadigma al-Qur'an: Pergulatan membangun tradisi dan aksi pendidikan Islam. UIN-Maliki Press.

Suprayogo, I. (2009). Universitas Islam unggul: Refleksi pemikiran pengembangan kelembagaan dan paradigma keilmuan Islam. UIN-Maliki Press.

Syahrul, S. (2016). Readines Frame: Analisis Kerangka Kesiapan dalam Transformasi Pendidikan Tinggi (Pengalaman Iain Kendari). Al-Ta'dib, 9(1), 162-181.

Wekke, I. S. (2013). Merawat semangat mengatasi keterbatasan. Menuju Indonesia Berkeadilan. Jakarta: Indonesia Social Justice Network.

Wekke, I. S. (2015), Meneropong Indonesia: Suatu anugerah berbangsa satu. Dalam Indonesia Kita, Satu, Thamrin Sonata. Jakarta: Peniti Media, 16-23.

Wekke, I. S. (2018). Higher education governance of muslim minority: efforts to be part of nation's development. Akademika: Jurnal Pemikiran Islam, 23(1), 1-26.

Wekke, I. S., \& Sahlan, A. (2014). Strategy in creating school environment: lessons from high schools in indonesia. Procedia-Social and Behavioral Sciences, 143, 112-116.

Wekke, I. S., Hermawanto, A., \& Ashrori, M. (2016). Keberagamaan Mahasiswa Di Perguruan Tinggi Wilayah Minoritas Muslim. Ulul Albab, 17(2), 135.

Welch, A. (2012). Seek knowledge throughout the world? Mobility in Islamic higher education. Research in Comparative and International Education, 7(1), 70-80.

Winter, A., Wiseman, J., \& Muirhead, B. (2006). University-community engagement in Australia: Practice, policy and public good. Education, citizenship and social justice, 1(3), 211-230.

Winter, R., Taylor, T., \& Sarros, J. (2000). Trouble at mill: Quality of academic worklife issues within a comprehensive Australian university. Studies in Higher Education, 25(3), 279294. 